\title{
Head of Soros fund rejects complaints over new grants
}

Moscow. The International Science Foundation (ISF) has allocated its second round of awards to scientists in the former Soviet Union. The grants, worth a total of US\$45 million, follow the first round of small emergency awards from the ISF, designed to fund successful applicants until mid-1995.

But whereas the distribution of the initial short-term grants was greeted with general approval, that of the second batch has left the ISF, set up with funding from the Hungarian-born financier George Soros, swamped with complaints. Some scientists, for example, are unhappy at the large number of applications that were turned down (only 3,000 grants were approved out of a total of 15,000 ).

Others are complaining that they received significantly less than they asked for, and claim that applicants were rejected even though they scored higher marks in the evaluation than successful colleagues.

But Alexander Goldfarb, director of the ISF's Washington office, rejects any charge of unfairness. He argues that the complex reviewing procedures used by the ISF - a mixture of peer review and assessment by expert panels - may well explain the high level of discontent.

Peer review resulted in more objective evaluations, he said, but the reviewer was not able to compare competing applications and rank them according to priority for funding. "The members of the expert panel are able to make such a comparison, even though their final joint decision may be by far more subjective." says Goldfarb.

According to Goldfarb, Western reviewers were often reluctant to give bad marks to impoverished colleagues in Russia and elsewhere. "If we were to rely just on those assessments, the average grant would have to be reduced to between $\$ 4,000$ and $\$ 5,000$, which is not enough even for food in Russia." The more stringent selection procedure adopted by the ISF allowed it to increase the average grant to $\$ 17,000$.

Despite the many complaints, the geographical distribution of the grants showed a similar pattern both to that of the earlier emergency grants and to that of papers published in scientific journals. As a result, Alexander Bratus, scientific secretary of one of ISF's panels, claims that the results of the long-term grant competition accurately reflect the situation in Russia.

Some scientists believe that panel members came under strong pressure from the applicants and other interested parties. Goldfarb admits that, despite precautions such as discouragement of lobbying and immediate intervention where it was suspected, some of this pressure may have filtered through.

Vladimir Pokrovsky

\section{Energy and biotechnology top Euro-Parliament's agenda}

Paris. When the European Union's (EU)'s 269 million voters go to the polls this week to elect a new European Parliament, they will be voting mainly on national issues, and most will be indifferent to science.

But the representatives they elect will have an increasing say in shaping the future of EU research. Although the parliament cannot make laws, successive treaties have given it increasing influence.

In particular, the Maastricht Treaty, which came into force last year, gives the parliament a veto on the budget of research under the Framework programme, which it insists carries with it the right to help shape EU research policy.

The parliament is supposed to compensate for the 'democratic deficit' of the two other main EU institutions, the European still unresolved. Commission (EC) and the Council of Ministers. The Maastricht agreement, however, has not been in force long enough for parliament to know how effective its veto and other new powers will be.

The first major test of the parliament's new powers will be a debate on an EU energy policy, which the commission is scheduled to propose during the six-month German presidency beginning on 1 July. Liberalization of Europe's energy monopolies will dominate the debate. But the parliament is also likely to seek a decentralization of energy production, and greater emphasis on renewable energy sources.

Past policies also suggest that, when it comes to discussing the fifth Framework programme, parliament will seek more funding for life sciences, environment, renewable energy and new industrial technologies, and less for costly information and telecommunications programmes.

Funding for fusion research - which receives aboutECU1 billion within the fourth Framework - may also experience more difficulty next time round. Some members refer to fusion as "the emperor with no clothes", and Detlev Sanland, who once tabled a motion against fusion research, is said to be a possible candidate to head the parliament's powerful budget committee.

In the immediate future, biotechnology will probably be the major research topic on the parliament's agenda. One of its first tasks, for example, will be to approve the content of the biotechnology and biomedi- cal programmes within the fourth Framework programme.

Another more controversial task will be to reach final approval of a new directive standardizing national laws on the patenting of life. After a voting muddle last month, parliament only adopted three amendments before attendance fell below the 260 required.

Under the new rules of the Maastricht agreement, approval now requires parliament and the Council of Ministers to agree on a single text in a "conciliation committee'. Parliament, feeling shortchanged, is likely to hold out for inclusion of some of the amendments it was unable to vote through last month.

Indeed, biotechnology has risen up the EU agenda following the release earlier this year of a white paper on competitiveness, growth and unemployment, by Jacques Delors, the president of the commission. This urged the EU to develop a strategy in biotechnology as a matter of urgency.

SAGB, a Brussels-based industry lobby group, has leapt on this, recently criticizing the EC for not doing enough to create "structural, regulatory, and fiscal incentives" to encourage investment in biotechnology.

SAGB also says that proposals made by the commission last week to reduce regulatory requirements for using genetically modified organisms (GMOs) - especially those considered low-risk - do not go far enough. But the parliamentary Green group is furious with the proposals, which they claim would lead to an unacceptable loosening of safety controls.

Claude Desama, president of the parliament's energy, research and technology committee (ERTC), says he "regrets" that the commission ignored his request for discussions before the proposals were issued. But he adds that a full debate will still take place with the commission and the council; parliamentary officials say that most committee members favour reducing regulatory and administrative requirements for GMOs.

Another plank of the white paper is a plan to build an EU electronic highway. Funding is one obstacle. But the biggest will probably be resistance among member states to the liberalization of telecommunications monopolies, while Desama wants assurances that the highway will cater for remote areas and small companies.

Declan Butler 